\title{
Repairing the law: The search for justice in the Nigerien gendarmerie
}

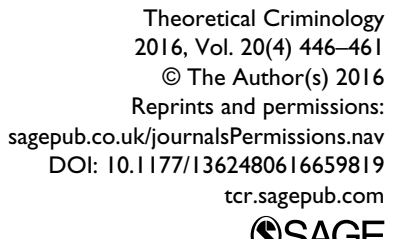

(9SAGE

\section{Mirco Göpfert}

University of Konstanz, Germany

\begin{abstract}
Sometimes it just seems wrong (or too much work) to enforce the law à la lettre. Then police officers may either turn a blind eye to particular situations or give you a warning instead of a ticket. The gendarmes in Niger do that as well, and they call this in Hausa 'gyara', meaning 'repair'. Taking seriously the gendarmes' perspective, their search for justice, as well as this notion of repair, I propose a little anthropological twist: it is not the gendarmes' application of the law that is deficient, but the law itself is. In their search for justice, the gendarmes in Niger repaired a law that they deemed inappropriate for policing the life worlds of the people they were confronted with.
\end{abstract}

\section{Keywords}

Dispute settlement, law enforcement, Niger, police and policing, repair

\section{Introduction}

It has become common ground for scholars of policing, that, as Waddington (1999: 5, emphasis in original) put it, 'the characteristic feature of policing is under enforcement of the law-not its enforcement'. Under-enforcement is mostly understood as the occasional (or frequent) non-enforcement of the law, depending on the police officer's discretionary decision to turn a blind eye to particular situations. The gendarmes in Niger, during my research with them, also often chose not to enforce the law. Just as often, however, they chose to truly under-enforce it - that is, enforce it, but not fully. In most cases, this meant turning a délit into a simple contravention (a criminal into a

\section{Corresponding author:}

Mirco Göpfert, Department of History and Sociology, Division of Social and Cultural Anthropology,

University of Konstanz, Box 38, 78457, Konstanz, Germany.

Email: mirco.goepfert@uni-konstanz.de 
non-criminal offence), or a contravention into a mere warning. This happened mainly in the course of what they called 'amicable arrangements' - the out-of-court settlement of cases.

The Hausa term for such arrangements is 'gyara'. Literally it means 'to repair'. 'Don Allah, a gyara', 'I beg you to repair', was probably the single, most common phrase spoken during my ethnographic research in the Nigerien gendarmerie, a rural police force in the West African Sahel. With this phrase, civilians begged the gendarmes not to send them to court and possibly into prison but rather to allow them to make amends instead. The victims knew that going to court meant that they had to spend months (and a lot of money) travelling back and forth between their homes and the courthouse, which was often dozens if not hundreds of kilometres away. In Niger, as in other West African countries, courts work often painstakingly slowly and cases are routinely adjourned (for Niger see Oumarou, 2011: 240-248; Tidjani-Alou, 2006; for Benin see Bierschenk, 2008: 117). The victims did not know when and if they would eventually be compensated. For them it was a terribly insecure investment. So usually both parties wanted the gendarmes to allow for an extra-legal settlement of the cases. And indeed, most cases were eventually settled by the gendarmes and outside the courts, even when a criminal law had been broken.

The Nigerien gendarmes usually tried not to stick too closely by the book, producing bureaucratic cases, files and sending everything to court. ${ }^{1}$ One of their primary aims was gyara, to restore peace, whether they were confronted with purely civil affairs (for which they had no legal mandate to resolve) or criminal cases. The gendarme, Hamza, ${ }^{2}$ explained this to me:

You see, making noise is not good. Even if it's a serious problem, you should always try to avoid noise. Because the people are condemned to live together. So if you separate them, this is not good. You must try and reunite them. ${ }^{3}$

Another gendarme, the brigade commander Adjudant-Chef Souley, added a phrase that I later came to understand as one of the main principles of the gendarmes' daily work: 'you should never leave black spots in the community'. Except when confronted with severe crimes, Souley and his staff sought to repair the harm caused to both the individual victim and the local community.

Instead of applying the law indifferently, the gendarmes rather tried to find alternative solutions to disputes and conflicts. When no law had been broken, the aim was to forge a consensus between the parties. The gendarmes would merely serve as guarantors of this agreement, which generally took the form of financial compensation. When a criminal law had been broken or rather when the gendarmes came to that conclusion, they as the 'soldiers of the law', as they called themselves, also felt offended. A law has been broken, and what is broken needs to be restored.

To achieve what the gendarmes understood as justice, that is, to repair the harm and restore the law, all parties had to lower their expectations, including the law. The Nigerien penal code (Code Pénal) and code of criminal procedure (Code de Procédure Pénale) both originate and still contain elements from the colonial era. Penal codes in Niger and other French-speaking African countries have rarely been modernized, 
so the gap between legal proscriptions and social notions of justice is particularly wide (Bierschenk, 2008: 114; Oumarou, 2011: 13, 185). According to the gendarmes, these outdated and 'foreign' laws were largely inappropriate for policing the life worlds of the people they confronted. This process could be seen as a prime example of discretion-led under-enforcement - a process which, as many scholars have shown, is a necessary principle of police work everywhere. ${ }^{4}$ In this article, however, taking the gendarmes' perspective and the notion of gyara seriously, I suggest that what appears as the under-enforcement or restraint of the law from one perspective may from another appear as the correction or 'repair' of the law. What the gendarmes thus repaired, I argue, was not only the relationships between conflicting parties, but the law itself. True, this is a particular kind of repair. The gendarmes often only produced makeshift solutions for more serious problems, just like the mai gyaran moto or mota, the mechanics for motorbikes or cars that I have met in Niger. The repair was hardly ever permanent, nor removed the cause of the damage, nor improved the substance of your car; but it allowed you to continue on the road-at least for some time. With this, I try to do what anthropologists may do best (e.g. Bierschenk et al., 2015: 12-13): propose a change in perspective. In that sense, it is not the application of the law that is deficient, as metaphorically expressed in 'under-enforcement', but the law itself.

I will develop my empirical argument by examining one particular case of assault and battery and only afterwards conclude with a discussion of its theoretical implications, drawing mostly on Aristotle's concept of epieikeia as the 'rectification' of the law and Max Gluckman's (1973 [1955]) description of the 'norm of the reasonable man' as necessary for bridging the gap between 'law in general' and 'law in action'. Cases like the one I present here were part of the bread-and-butter business of the gendarmes in socalled brigades territoriales, the street-level units of the Nigerien gendarmerie, the country's rural police force..$^{5}$ One brigade had between 10 and 25 gendarmes working there, but due to shift rotation, on the job training and temporary postings, usually no more than six would be effectively present. Here, gendarmes encounter civilians and investigate criminal cases as auxiliaries of the public prosecutor. ${ }^{6}$

Between 2009 and 2014, I spent as a participant observer one-and-a-half-years in different units in several regions of the country: criminal investigation departments; traffic police; administrative units; and, mostly, in regular brigades territoriales. I spent most of the gendarmes' working hours sitting with them in or in front of their offices discussing their work. I also followed them on criminal investigations (see Göpfert, 2015), spent evenings chatting with those on night duty and occasionally invited them, or they invited me, for dinner or a drink. ${ }^{7}$ Most of the time, however, I witnessed them 'repairing' the law.

\section{Harm and offence}

One morning a 16-year-old boy came to the brigade; he had cuts and bruises and his face was swollen. When he came closer, Chef Hamza recognized him as a pedlar who sold coffee, tea and bread at the local bus station. Without waiting for the greetings and out of concern for the boy, he asked him what had happened. A mechanic who also worked at the bus station had 
beaten him up, he said in such a timid voice that Chef Hamza and I barely heard him. The mechanic had ordered and drunk a coffee and eaten a piece of bread and refused to pay afterwards. The ensuing argument quickly turned into a fistfight and the mechanic, perhaps in his mid-20s, was much stronger and beat up the boy badly. Chef Hamza asked which mechanic it was. The boy did not know his name but described the workshop where the bully worked and Chef Hamza's hunch turned out to be right. He got visibly angry: 'How often have we had him here, this thug? His relatives come, we hit them with a fine of 12,000, 8,000, 12,000 and every time they pay for him!' He told the gendarme, Moussa, to give the young man a summons for the mechanic.

Not only had the mechanic breached his commercial contract with the boy when he ordered and consumed coffee and bread without paying, but he also beat him up afterwards. In legal terms, it was the délit assault and battery (coups et blessures volontaires). The Nigerien penal code states that, '[e]very person who has wilfully injured or struck, or committed any other violence or assault, shall be punished with imprisonment of three months to two years and a fine of 10,000 to 100,000 franc or one of these penalties only' (République du Niger, 2003: Art. 222, trans. MG). The mechanic had clearly broken criminal law; according to the gendarmes there was no doubt about that. But Chef Hamza was also offended. He knew the mechanic who had already been summoned to the brigade several times. He was well aware that the mechanic had been released just as often with a fine which his relatives paid.

In similar cases, gendarmes often sent away the complainant, dismissing the incident as mere brawls among young adults, nothing unusual, and that, 'it was not worth' putting their time and energy into this kind of 'futilities'. The gendarme Amadou explained that this was the difference between a good and a bad gendarme: 'You should never say, "it isn't worth it". Even if the damage caused is small, you should never say, "it's a futility". Otherwise the poor would never recover their rights.' Some gendarmes were more inclined to take over cases in which a lot of money was at stake. That meant that the gendarmes had a prospect of additional income after a successful arrangement. But a good gendarme should not limit his motivations to possible income; he should himself also feel offended both in his role as the defender of justice and through his empathy with the victim. Since most gendarmes came from similarly poor and rural areas, they were particularly sensitive to their "rural brothers and sisters" difficulties, needs and expectations, they said. Justice, however, was a rather diffuse thing. And it should perhaps, as Laura Nader (1990) reminds us with regards to 'harmony', be understood as an ideology with political implications. As I have shown elsewhere, in this context justice is like security first and foremost about the protection, care and definition of the community (Göpfert, 2012: 66). So even when the gendarmes were not very empathetic with the victim, they were at least sensitive to whether somebody wilfully disrespected communal peace and thus the gendarmes' ambition to maintain it - that is, the core of their professional identity (Beek and Göpfert, 2013b: 113-115). Chef Hamza's anger was not so much caused by the fact that the mechanic had beaten up a younger boy, but rather by his constant disrespect for the gendarmes and the law and the fact that he could count on his relatives' support. In this light, the mechanic had done three things: he had caused harm to the boy; broken the law; and offended the gendarmes. 


\section{Hearing and judgment}

The injured boy came back to the brigade about one hour later, followed at a short distance by the mechanic. Chef Hamza called them to come near and they squatted down in front of him. He asked the boy to repeat what had happened. He was very shy, and was barely audible, stuttered and kept touching the cuts on his lips. 'Ya isa', 'That's enough'; Chef Hamza interrupted him harshly and pointed to the mechanic. 'This talk is not true', the latter started. He had not even finished his first sentence when Chef Hamza interrupted him harshly. 'Baka miji ba ne!', 'You are not a man! Only here you have courage because you know that your relatives will pay for you. But down there, beating up this child?' Chef Hamza got up from the bench and said, 'Man, that's a thug, lock him up.' Moussa got up and took the mechanic into the building, wrote down his name, profession, date and place of birth, names of his mother and father and locked him into the cell.

When the two parties were assembled at the brigade, the collective hearing started. As usual, the complainant spoke first, then the suspect. After that, the gendarmes delivered a judgment, a clear definition of roles. The boy was the victim; the mechanic was not even treated as a suspect but as guilty, a bully and a thug - not only vis-a-vis the boy, but also in relation to the gendarmes. The judgment was first verbalized, then materialized when Chef Hamza had Moussa detain the mechanic. Moussa noted the mechanic's particulars in the arrest registry, forced him to take off his shirt and shoes and locked him into the cell. In most cases after they had uncovered the truth and defined the role of the offender, the gendarmes routinely incarcerated the offender. This had several effects. First of all, the mechanic or any other person who was put into the cell was forced to take on the role ascribed to him. He was no longer in a position to negotiate with the gendarmes or at least have his version of the story heard. And the complainant was reassured by the gendarmes' judgment in his favour.

But it was unclear whether the mechanic was now being held by the strong grip of the law or just by the gendarmes. To put it in Jan Beek's (2011: 201) terms: had the gendarmes' already drawn the register of formal law enforcement or was this some sort of instant punishment as part of the register of sociality? It could be either or both: the initiation of a legal procedure or the gendarmes' violently punishing him in response to what they perceived as a threat to their status (see Alpert and Dunham, 2004: 172-176; Conti, 2009: 411-413). Or was it just a humiliating exercise in social discipline (see Choongh, 1998: 227)?

At this point, both parties could not know how the gendarmes would proceed: write a report or find an arrangement, in other words, enforce the law or not. To the boy and the mechanic it was not clear which role the gendarmes had adopted. If the gendarmes were themselves unsure which role to take on, they would call the prosecutor (depending on their personal relationship with him) - the formal head and supervisor of any criminal investigation. The latter would then tell them to find an arrangement, to merely fine the offender or make the procedure, depending on the national or regional politique pénale, a 'policy relating to particular offences' (Hodgson, 2002: 236, fn. 39), but also on his own workload and his trust in the gendarmes' abilities as arrangers (because he would not want to take the blame for possible backlashes). In short, during the hearing, the 
gendarmes made a full assessment of what has been broken and might need repair, but also whether it could be fixed at all.

\section{'What do you want?'}

Shortly after the mechanic had been locked into the cell, Adjudant-Chef Souley came back from some errands. Chef Hamza directly approached him and told him about this affair. Souley sat down on a bench beside the boy and asked him what had happened. The boy, still squatting on the ground, talked so shyly that Souley urged him to speak up several times. Then he asked Chef Hamza whether the mechanic had already confessed. Hamza and the other gendarmes present said that whether he had confessed or not... 'we know this thug' Souley then asked the boy 'To, me kake so?', 'What do you want?' but the boy could hardly talk. Seemingly intimidated by Souley's impressive bodily presence and aura of authority, he was staring at the ground and nervously touching the wounds on his face and did not say a word. Adjudant-Chef Souley told him to go to the hospital, have his wounds taken care of and come back with the receipts for the treatment. When the boy left, Adjudant-Chef Souley explained that this is what the mechanic always did: pick a fight with younger and weaker boys, preferably those like this one, who were strangers in the town and had no relatives here, who worked hard just to earn their daily bread.

The mechanic was in the cell; this looked like enforcement. Then Adjudant-Chef Souley uttered the central question: 'Me kake so?'-'What do you want?' The gendarmes asked this question in all cases except for cases of severe crimes, such as murder or kidnapping. In the latter case, the gendarmes made clear that their activity had nothing to do with the complainant's request but with their legal or superior moral mandate. When they asked, 'What do you want?' the gendarmes insinuated that all their ensuing activities depended on the complainant's choice. Sometimes the question was followed by a second one: 'Kana so an kai shi prison?'- 'Do you want us to put him in prison?' Or they said: 'In kuna so an kara... bashi koma gida!' - 'If you want that we proceed, he will not return home.' This implied that the gendarmes' strict law enforcement depended on whether this was the complainant's will. I have never witnessed somebody replying, 'Yes, they should put him in prison.' Putting somebody in prison would in most cases mean social disaster. It would mean stigmatizing somebody as an intrinsically dangerous person and of absolutely no social value. Furthermore, it would put enormous pressure on the prisoner's family; an imprisoned man could no longer look after his family, instead they now had to look after him. And since in the rural communities where the gendarmes worked, there was almost always some kind of relationship between the families of the victim and the offender, even if only an ethnically based joking relationship (see Tamari, 2006; Verne, 2004), the prison-option had to be absolutely avoided in order to prevent social rupture. Again: 'never leave black spots in the community!' Civilians thought quite similarly, and this is why they too always opted for arrangements. Only when everybody agreed that the offender was, in fact, of no social value and of intrinsic danger to the whole community, civilians urged the gendarmes to take that person away-and thus draw the boundary of the community.

The gendarmes seemed to leave it to the complainants' discretion which exact role they would adopt: that of the law enforcer, punisher, mediator and so on. With this, I 
suggest, they tried to grasp popular ideas about the gravity of a given offence. In other words, they tried to understand popular conceptions of right and wrong and of who was and was not perceived as being part of this local community. A superior officer once told me that the gendarmes, in their interface position between the law and the people, and in order to do a good job had to 'find an understanding with the population. They have to study: what is their vision of security and justice? And by doing that, they adopt, even without being aware of it, a client-centred perspective.' The gendarmes knew very well that civilians could easily interpret the indifferent application of the law against fundamental local convictions as misuse of power and they would call a march on the gendarmerie station. Although I have never witnessed but only heard stories about a protest march, I was struck by how seriously the gendarmes appeared to be concerned with them.

\section{Preparing the repairs}

A couple of minutes after the boy had left to seek treatment at the hospital, Adjudant-Chef Souley asked Chef Hamza exactly which mechanic they had locked up. Hamza described the location of the workshop he was employed in, what last affair had brought him here and who his father was. It turned out that Souley also knew both the mechanic and his father; he had his phone number and was about to call the father when Chef Hamza said: 'Ga shi', 'There he is', pointing at an elderly man walking towards the brigade. Souley put his mobile phone in his pocket and waited for the man to come closer. He came, respectfully greeted the gendarmes and said that he had learnt that his son was here. 'Don Allah a gyara', he said in Hausa, 'I beg you to repair.' Adjudant-Chef Souley replied harshly: 'Tsoho, irin wannan fitina bamu yi gyara!' 'Old man, we don't arrange this kind of disobedience!'8 The father then squatted down and began complaining about his disobedient and useless son, about how he was sick of him getting into trouble and that he should instead marry, have children and live a decent life. Chef Hamza got up from the bench, walked towards the building and called the man, 'Ka zo!' to follow him. He opened the cell door and said that they could talk for a bit in the courtyard.

When Adjudant-Chef Souley dialled the number of the mechanic's father, even though he hung up when he saw the man coming towards the brigade, he wanted to have the suspect's ally come to the brigade. In most cases, however, Adjudant-Chef Souley or other brigade commanders did not have the phone numbers for suspects' relatives. Then the gendarmes slowed things down by not writing the case file quickly, extending the limbo in which complainant and suspect found themselves. Usually this meant that the gendarmes kept the suspect in custody for 48 hours, the legal maximum; sometimes longer. During these two or more days, one or more of the suspect's relatives or his or her neighbourhood chief, would come to the brigade to talk to the gendarmes and beg for an arrangement: 'Don Allah a gyara!' They would also talk to the complainant and their family and beg them to withdraw their complaint. They knew that they had to negotiate with both the complainant and the gendarmes. However, the gendarmes would always say that in this particular case, an arrangement was impossible. And then they would wait.

If nobody came to support the suspect, the gendarmes allowed him or her to contact supporters themselves. Although they were in custody, most of the time they were not 
confined in the cells but rather allowed to sit in the courtyard. They could not leave the brigade (although about once a month somebody did run off) but they received visitors, talked to the complainant and could even use their mobile phones. Sometimes the gendarmes would even top up the suspect's phone and allow him or her to charge its battery in the brigade's office. Some had installed their chargers, as if they were living in the brigade: the charger was constantly in the multiple socket outlet and the cord coiled around the leg of the office table, plugging and unplugging their phones every few hours. When a gendarme working in the office heard it ringing, he would even get up from the computer and hurry to bring it to the suspect sitting in the courtyard.

Most of the suspects' telephone conversations were about money. The suspects tried to find friends and relatives who would help them pay compensation to the complainant. 'If you have some money, bring it here!' I heard some of the detainees say on the phone. Others were more offensive; they tried to mobilize contacts that would help them refute the allegations made by the complainant. 'I'll counter-attack', a suspect once said to himself while he was searching through the directory on his phone. A counter-attack could also mean that the suspects tried to mobilize people that would use their influence and intervene to make the gendarmes work in their favour (see Beek, 2012: 559-560). The gendarmes did not like such interventions; but enabling them was a way for them to identify influential friends a detainee might have. Sometimes the interventions were so intense that, as Christian Lund (1998: 208) describes with regards to land disputes in eastern Niger, it was 'not the power of the litigants that was confronted, but the powers that they were able to mobilize'. Interventions by these 'powers' would cause the gendarmes trouble if they occurred after the arrangement had been reached. When it occurred during the consensus finding, the gendarmes could still adjust the strictness and clemency of their judgment so that they would not offend the influential relatives of the parties, but do them a favour and without appearing as puppets of the powerful. When the intervention occurred after reaching the arrangement and closing the case, they had to justify why they had not worked by the book, and they had to defend the judgment they had made during the arrangement. In some cases they even had to re-open and revise the case; and in order not to burn their fingers again, they would quickly write a report and forward the case to the prosecutor for him to deal with the interventions.

Allowing the suspects to use their phones and simply slowing things down was a way for the gendarmes to suggest that an alternative, extra-legal solution to the conflict might be possible; that repair might be possible. But it was also a way for the gendarmes to make sure that when restraining the law, they would not hurt themselves. To paraphrase a policeman Jeffrey Martin (2007: 687) cites: the arrangement, just like the law, is like a knife. And each gendarme had to be a 'skilful surgeon if he himself is not to lose control of the blade'.

\section{Repairing the harm}

The boy came back in the afternoon with a couple of plasters on his face and a plastic bag with some medication. He did not talk to any of the gendarmes; he just sat down on a mat in the shade and waited. When Adjudant-Chef Souley came back from a break, he asked the boy for the receipt for his treatment, glanced at it and handed it back to him, and told Amadou to take 
the boy's statement. Amadou got his cahier de declarations from the office, sat down on a bench and asked the boy to sit beside him. When he had finished, he handed the notebook to Adjudant-Chef Souley, together with the receipt for over 2500 Franc CFA for the medication the boy had bought. Souley read through the declaration and stopped at the last paragraph, which he read aloud: 'I press charges and I demand the sum of 50,000 franc as compensation.' 'You want 50,000 franc?', Souley asked him angrily. All the gendarmes started laughing. 'You know exactly that he doesn't have this kind of money! Do you want to create him still more problems?' He asked Amadou to bring the mechanic. When he came out of the cell, rubbing his eyes in the bright sunlight, Souley told him to give the boy 5000 and to bring it to the brigade tomorrow morning. 'Why did you beat up this child? Isn't he your little brother?' And if he ever caused any trouble again in Godiya, Souley would make sure that he would be taken to prison. 'We have your name! If tomorrow somebody files a complaint against you, by God, you will not go home!' Then he sent him away with his father. The complainant was still sitting there unsure what to do. After a while, Adjudant-Chef Souley walked toward him and gave him a 5000 franc note. 'Now there stands nothing between you! Do you understand? It's over!' The boy thanked him and the other gendarmes and went away.

Souley enforced an arrangement that in his eyes was just and satisfying for all participants. The boy received compensation of 5000 francs for his medical expenses and his pain and suffering. In most cases, however, the arrangement was negotiated between complainant and suspect via intermediaries, families or chiefs. But they were never allowed to negotiate right at the brigade. ' 'You will talk some place else', Adjudant-Chef Souley used to say to them, 'somewhere under a tree, somewhere in town, some place where nobody can hear you, and I don't even want to see you. I don't give a damn about it!' Had the two parties reached a consensus, they or the chief negotiator, in most cases a representative of a chief, came back to the brigade to present the result to the gendarmes. The consensus contained the amount of compensation the perpetrator would pay to the victim. This usually covered the victim's medical expenses, the estimated price of the stolen or damaged goods and the victim's expenses while searching for the suspect or coming to the brigade. If the brigade commander felt that one of the parties had somehow been pressured into accepting the consensus, which meant that the brigade commander deemed the amount of compensation too high or too low, he again threatened to write a report and forward the case to court. This is also what he did when the parties had not reached an agreement. In such cases, Adjudant-Chef Souley said, 'I use a bit of pressure. I talk to them with red eyes and unsettle them, that I will write the report, and then you will see that they start to think.'

In the case of the boy whom the mechanic had beaten up, the two parties did not negotiate. The boy was much too young to negotiate with the mechanic's father and he had no relatives in town who would support him and negotiate in his stead. The gendarmes asked him how much he wanted in compensation; and Adjudant-Chef Souley then rebuked him for demanding far too much. In view of the boy's medical expenses of 2500 franc and the fact that his injuries were not serious and that the mechanic was almost as poor, Souley felt that compensation to the amount of 50,000 franc was grossly unfair (and unrealistic); 5000 franc was the right sum to repair the harm caused. As the boy had no other option, he simply had to agree; the mechanic and his father had no choice but to agree because anything was better than being sent to court and possibly to prison. 
The resolution was always the same: a moral lesson and the gendarmes' stressing that the problem was solved once and for all, that all ill will had been removed. Sometimes the moral lesson Adjudant-Chef Souley gave in the courtyard of the brigade took some 15 minutes and was for every other civilian and every gendarme to hear. Everybody would stop talking and listen. In a defamation case, he talked about how to behave towards your neighbour, live peacefully together, that your closest relative is your neighbour; in the case of alleged adultery he talked about the difficulties of being married but that family was, after all, the highest good you could have; in the case presented above, he told the mechanic to be peaceful and have sympathy with his 'little brother' who struggled just like him to earn enough to have something to eat in the evening; and in almost every case he ended by saying that now nothing stood between the two parties. The gendarmes had repaired the harm, and they had at least tried to repair the relationship between the victim and the offender, and thus peace within the community.

\section{Closing the case}

When the two opposing parties had reached an agreement, perhaps the harm was repaired, and maybe the relationship between the two as well. But the law had still been broken. An agreement between the conflicting parties was only the precondition for a full arrangement. Once, I asked Chef Hamza whether the withdrawal of a complaint was sufficient for an arrangement and he replied harshly, 'Whether there is a complaint or not, we don't give a damn! If he has offended the law, the state has to regain his rights, too!'

For the gendarmes, this meant that the offender had to be punished in some way. In cases of severe crimes this was simple: the offender had to be brought before the court and sent to prison. In cases they tried to arrange, the gendarmes themselves punished the offender. They put the offender into the cell at the brigade, like they did with the mechanic. The gendarmes often explained this as a means of correction, 'to intimidate them so that tomorrow they will not do the same thing again', as Chef Hamza put it. This corrective intention notwithstanding, incarceration also had a purely punitive dimension (see Beek and Göpfert, 2013a: 488-489). In addition to that, the gendarmes would have most offenders pay a fine - a monetary 'reparation'. The amount of the fine was at the discretion of the gendarmes and could also be negotiated. Often the offender, his family or his chief would plead to reduce the fine; and the gendarmes themselves were careful not to impose too high a sum because they did not want these civilians to feel as if their treatment was grossly unjust. Then they would complain, often with the help of influential friends or relatives, about the gendarmes' misconduct, which could land the gendarmes in enormous trouble. Whether the offenders received a 'reçu' - a 'receipt', as the gendarmes called the tickets they handed out — and thus whether the money went into their own or the state's pocket was another question and depended on whether the gendarmes felt there was a high risk of complaints later. ${ }^{10}$

Imposing a fine at the brigade meant in most cases that a délit was downgraded to a contravention, the category for the least severe offences punishable by mere fines. The mechanic though, who had beaten up the boy and thus clearly committed the délit of assault and battery, did not have to pay any fine. In other words, the délit did not turn into a contravention but it simply dissolved. This was an instance of extreme under-enforcement; or 
an example of how the gendarmes repaired the law, not because it has been broken, but because they felt it was inherently deficient.

\section{Repairing the law}

There is always a gap between law and action. The law because it is general and has a totalizing claim, is always and necessarily in tension with concrete, practical reality. Aristotle in the Nicomachean Ethics (Aristotle, 1925) thus introduced the notion of epieikeia, which is translated as 'equity', 'correction' or 'rectification' of the law (Shiner, 1994: 1247, 1252) or 'Berichtigung des Gesetzes' in German (Gadamer, 1999 [1960]: 323). In this sense, applying the law demands that a good judge with the virtue of equity not apply it $\grave{a}$ la lettre. 'In restraining the law, he is not diminishing it but, on the contrary, finding the better law' (Gadamer, 1975: 316), or even finding 'justice which lies beyond the written law', as Roger Shiner (1994: 1247) cites Aristotle. 'Written law inevitably falls short of the standard of applicability that it wears on its linguistic face. Written law speaks universally and absolutely, but it has no right to do so. Equity corrects that deficiency' (Shiner, 1994: 1255). ${ }^{11}$ Max Gluckman in his seminal analysis of the judicial process among the Barotse calls this the 'norm of the reasonable man'. According to this norm, 'the judges may develop and even alter the law' (Gluckman, 1973 [1955]: 160) in order to bridge the rift between 'law in general' and 'law in action' (Gluckman, 1973 [1955]: 291; see also Aubert, 1969: 288). ${ }^{12}$

The gendarmes in Niger, however, went beyond what for Aristotle was epieikeya and for Gluckman was the norm of the reasonable man. They not only had to bridge the gap between law and action; they also had to apply a law that they deemed inappropriate for policing the life worlds of the people they confronted. So what they did was gyara: repair work. Anyone who ever had their car or motorbike repaired at a small garage in a West African rural town or village knows what repair work there means. Most of the time, the mai gyaran moto or mota, the mechanics for motorbikes or cars that I have met during my stay in Niger, produced only makeshift solutions for more serious problems: a hole in a car tyre that they sew up by hand, a V-belt that they replaced with a homemade clothbelt and so on. The repair was hardly ever permanent, nor removed the cause of the damage, nor improved the substance of your car; but it allowed you to continue on the road-although you never knew for how long. It could be, depending on the kind of repair, for a few hours (then you would be angry), a couple of weeks (that was good!) or even months (that was great!). Sometimes the local makeshift V-belt was better adapted to the harsh climate in the Sahel and worked for even longer than the imported original.

The gendarmes' repairing the law was similar. It was neither permanent nor had any consequences for the written and codified law of the penal code. There was no such thing as a feedback loop through which the gendarmes' repairs would alter the 'concrete law' (Von Benda-Beckmann and Von Benda-Beckmann, 2006: 13), for example the law against assault and battery. ${ }^{13}$ Rather, what they repaired was the law as a totality, as described by Bruno Latour (2010: $254 \mathrm{ff}$.). According to Latour (2010: 255), 'it is as if there were no degrees in law: either one is fully into it, or one is not in it at all and begins to talk about something else'. The gendarmes would perhaps try to prove Latour wrong. They talked about the law and many other things at the same time, things they subsumed 
under the label 'the social'. The gendarmes never drew the register of formal law enforcement alone; they asked the complainants what they wanted them to do; and they always took non-legal aspects into consideration making it hard for civilians to predict how the gendarmes would proceed.

The gendarmes are in a sense the gatekeepers of the legal machinery. ${ }^{14}$ They were the ones who decided what would enter (or be excluded from) the chain of legal-bureaucratic translations, inscriptions and purification (see Latour, 2010: 253). By doing so, the gendarmes not only prevented the legal machinery from getting clogged up with too many cases, as prosecutors assured me time and again - in a kind of preventive repair against system breakdown and, at the same time, for the creation of the organization's external boundaries (Bierschenk, 2008: 118-119; Luhmann, 2013 [1983]: 41). Not through purification but the 'contamination' of the law with what they called 'the social', the gendarmes repaired the law as a totality, and, in their eyes, decidedly so for the better.

\section{Conclusion}

In this article, I have demonstrated how the gendarmes arrived at settlements when criminal law was offended, how they repaired the relationship between the disputants, that between the designated offender and the law, and thus how they repaired the law itself. When I asked the gendarmes about these arrangements, they referred to different moral and pragmatic considerations. First, keeping a case at brigade level and finding an arrangement opened up the possibility of substantial additional income for them. Second, even the prosecutors preferred arrangements to strict prosecution. 'Arrange this at your level', he told them over the phone, or 'impose a fine on them' although the case was ostensibly more severe than a simple contravention. One prosecutor told me that, 'a reconciliation is better than a good ruling' because a ruling would clearly define who was right and who was wrong; and this would eventually lead to the rupture of the relationship between the two parties - something that had to be avoided at all costs. Third, the gendarmes said that they respected the wishes of the civilians who brought their problems to them. 'The people who come to us to file a complaint, they themselves ask for an arrangement', Chef Hamza explained. As they knew that going to court would do nothing but delay their compensation, if they are compensated at all. Fourth, and perhaps most importantly, the gendarmes often felt that strict law enforcement was unjust. But contrary to the often-stated claim that the sense of justice among police officers and gendarmes translates into them making decisions that serve the privileged and exclude the marginalized (see, for example, Corsianos, 2001: 114), the gendarmes were much more equitable and sensitive to the rural communities' needs and expectations - not least because most gendarmes had similar backgrounds. In Adjudant-Chef Souley's words:

Applying the rigour of the law, for the poor this is ... this means creating situations that are yet more disastrous than the act the guy has committed. You have to understand some things, follow certain norms. Especially when you're a man of the law. Because it can happen to everyone. Today we are in a world that is ...ignorant. People all the time, all the time, even while they're eating they will commit an offence! [he laughs] And how do you ...? You cannot be rigorous. I don't want the victim to be left alone, but I also do not want that the offender is 
overly penalized. Really, people have always opted for peace. And that's what makes us try and find arrangements.

From a state law-centred perspective, what the gendarmes did during these arrangements appears as the under-enforcement of the law. They used their discretion not to do what the law dictated. The application of the law was deficient. From a different perspective, they did what they felt morally obliged to do. They repaired a law that they deemed unjust. Not its application, but the law itself is deficient. If Marilyn Strathern (1996: 522) argues that "law" cuts into a limitless expanse of "justice", then the gendarmes would argue that they, in search of justice, cut into a limitless expanse of law.

In short, what I suggest is a change of perspective. To leave aside the paradigmatic law-centred perspective for a moment, and adapt one that is more sensitive to those actors' views and practices that have to apply the law on a daily basis. This, in itself, is not revolutionary, particularly with the ethnographic studies of policing à la Bittner $(1967,1974)$ and Skolnick (1966) in mind. Yet the little anthropological twist I propose means to also take seriously local concepts of law enforcement, dispute settlement and the search for justice, in this case: gyara, repair work. This is neither to shift responsibility (or deficiency) from one side to the other, nor to absolve police officers or gendarmes from occasional arbitrariness and abuse of power, nor to hide the fact that the gendarmes' repair work was, pure and simple, illegal (which in some cases caused them not only profound yet vague inner troubles but also concrete and painful disciplinary procedures). This is merely to give an example of what an 'anthropological criminology' may have to offer to broader criminological debates about crime, punishment and the application of the law.

\section{Acknowledgements}

Drafts of this article were presented at the Annual Meeting of the American Anthropological Association, Washington, DC, in December 2014, and during the anthropological seminar series held at the University of Konstanz. For critical comments, I am grateful to Jan Beek, Judith Beyer, Thomas Bierschenk, Jan Budniok, Thomas G Kirsch, Carola Lentz, as well as the organizer and discussants of the workshop at the AAA meeting 2014 and the participants of the seminar in Konstanz. Above all, I am deeply grateful to the gendarmes in Niger who have accepted me among them.

\section{Funding}

The research this article is based on was made possible by the financial support of the German National Academic Foundation, the Johannes Gutenberg University Mainz and the German Research Foundation (DFG) as well as by the support offered at the Laboratoire d'Études et de Recherches Sociologiques sur les Dynamiques Sociales et le Développement Local (LASDEL), Niamey, and the Institute for Advanced Study Konstanz, where I was a fellow while writing this article.

\section{Notes}

1. For the production of case files by the Nigerien gendarmerie see Göpfert (2013).

2. All names are pseudonyms. 
3. All quotations from the gendarmes are drawn from interviews or field notes. They were recorded in French or Hausa; these are my translations.

4. See Bittner (1967, 1974: 23); Feest and Blankenburg (1972: 19); Goldstein (1960); Ignatieff (1979: 445); Monjardet (1996: 38); Owen (2013: 59); Reiner (2000: 19); Waddington (1999: 38).

5. Gendarmes differ from police in the following way: the national police are under the ministry of the interior, the gendarmerie under the ministry of defence; police have civil and gendarmes military status (and the latter serve as military police); police work in towns, gendarmes in villages. In terms of their daily work, however, gendarmes and police have essentially the same tasks: traffic control; public order policing; and criminal investigations.

6. Auxiliaries of the prosecutor are called officiers and agents de police judiciaire. Rank-andfile gendarmes were agents de police judiciaire; their task is to assist the officiers de police judiciaire (OPJ) who direct criminal investigations, author case files and are directly accountable to the prosecutor.

7. For more details on my access to the gendarmerie see Beek and Göpfert (2011).

8. In this context, 'fitina' can mean annoying behaviour, disobedience and cause of trouble.

9. By sending the negotiating parties away from the office building, the gendarmes tried to maintain a clear functional differentiation of spaces and thus their occupational image as strict law enforcers: the brigade is not a place for negotiations. The management and functional differentiation of spaces in and around police and gendarmerie stations anywhere can be understood as a means of the police officers' and gendarmes' face-work (see Ericson, 1989: 211; Holdaway, 1980: 82-84).

10. The prospect of being able to earn some extra money was, of course, another incentive for the gendarmes to not apply the law à la lettre. However, considering that the gendarmes worked in a blatantly underfunded institution and had to pay for most of the office materials, their uniforms, boots, handcuffs, fuel for the brigade's vehicle and so on out of 'their own' pockets, the normative label 'corruption' would not do justice to this complexity.

11. This understanding is also reflected in the global trend of 'restorative justice' that institutionalizes the non-enforcement of the law in the form of specialized organizations charged - by the courts - with conflict resolution through mediation instead of criminal prosecution (Aubert, 1969; Comaroff and Comaroff, 2004: 189; Johnstone, 2002; Roche, 2006: 219 ff.; Steinberg, 2010: 56; Wright and Galaway, 1989). What is generally subsumed under 'restorative justice' is, however, not limited to criminal justice programmes but takes place in schools, welfare, health and environment agencies (Roche, 2006: 217-218), although, as Roche (2006: 235) argues, 'it works best when it is used in conjunction with the threat of tougher enforcement'.

12. Jeffrey Martin (2007: 691) describes a similar principle at work in the Taiwanese police: '[b] y contrast to the harsh cutting edge of law, reason is described as a circular, rounding, and smoothing quality that fits the law to context'. For a critical discussion of Gluckman's concept of the reasonable man see Epstein (1973).

13. This would arguably be closer to Elizabeth Povinelli's (1998: 586) description of 'repairing the law' in Australia as a legislative response against racial and cultural intolerances.

14. Really the 'first' gatekeepers are, of course, the victims of a crime (see Gottfredson and Gottfredson, 1988: 15-18).

\section{References}

Alpert GP and Dunham RG (2004) Understanding Police Use of Force: Officers, Suspects, and Reciprocity. Cambridge: Cambridge University Press.

Aristotle (1925) Ethica Nicomachea. Trans. Ross RC. Oxford: Clarendon Press. 
Aubert V (1969) Law as a way of resolving conflicts: The case of a small industrialized society. In: Nader L (ed.) Law in Culture and Society. Chicago, IL: Aldine, 282-303.

Beek J (2011) 'Every car has an offence on it': Register polizeilichen Handelns bei Verkehrskontrollen in Nordghana. Sociologus 61(2): 197-222.

Beek J (2012) 'There should be no open doors in the police': Criminal investigations in northern Ghana as boundary work. Journal of Modern African Studies 50(4): 551-572.

Beek J and Göpfert M(2011) ‘Ground work' und 'paper work': Feldzugang bei Polizeiorganisationen in Westafrika. Zeitschrift für Ethnologie 136: 189-214.

Beek J and Göpfert M (2013a) Police violence in West Africa: Perpetrators' and ethnographers' dilemmas. Ethnography 14(4): 477-500.

Beek J and Göpfert M (2013b) State violence specialists in West Africa. Sociologus 63(1-2): $103-124$.

Bierschenk T (2008) The everyday functioning of an African public service: Informalization, privatization and corruption in Benin's legal system. Journal of Legal Pluralism 57: 101-139.

Bierschenk T, Krings M and Lentz C (2015) Anthropology in the twenty-first century: A view of, and from, Germany. Working Papers of the Department of Anthropology and African Studies of the Johannes Gutenberg University Mainz 160, JGU-Ifeas.

Bittner E (1967) The police on skid-row: A study of peace keeping. American Sociological Review 32(5): 699-715.

Bittner E (1974) Florence Nightingale in pursuit of Willie Sutton: A theory of the police. In: Herberg J (ed.) The Potential for Reform of Criminal Justice. Los Angeles, CA: SAGE, $17-44$.

Choongh S (1998) Policing as Social Discipline. Oxford/New York: Clarendon Press/Oxford University Press.

Comaroff JL and Comaroff J (2004) Criminal justice, cultural justice: The limits of liberalism and the pragmatics of difference in the new South Africa. American Ethnologist 31(2): 188-204.

Conti N (2009) A visigoth system: Shame, honor, and police socialization. Journal of Contemporary Ethnography 38(3): 409-432.

Corsianos M (2001) Conceptualizing 'justice' in detectives' decision making. International Journal of the Sociology of Law 29: 113-125.

Epstein AL (1973) The reasonable man revisited: Some problems in the anthropology of law. Law \& Society Review 7(4): 643-666.

Ericson RV (1989) Patrolling the facts: Secrecy and publicity in police work. British Journal of Sociology 40(2): 205-226.

Feest J and Blankenburg E (1972) Die Definitionsmacht der Polizei: Strategien der Strafverfolgung und soziale Selektion. Düsseldorf: Bertelsmann.

Gadamer HG (1975) Truth and Method. London: Continuum.

Gadamer HG (1999 [1960]) Hermeneutik 1. Wahrheit und Methode. Tübingen: Mohr.

Gluckman M (1973 [1955]) The Judicial Process among the Barotse of Northern Rhodesia. Manchester: Manchester University Press.

Goldstein J (1960) Police discretion not to invoke the criminal process: Low-visibility decisions in the administration of justice. Yale Law Journal 69(4): 543-594.

Göpfert M (2012) Security in Niamey: An anthropological perspective on policing and an act of terrorism in Niger. Journal of Modern African Studies 50(1): 53-74.

Göpfert M (2013) Bureaucratic aesthetics: Report writing in the Nigérien gendarmerie. American Ethnologist 40(2): 324-334.

Göpfert M (2015) Ethnographische Überlegungen zu Polizeiarbeit in Niger: Geschichten hören, verstehen und schreiben. Paideuma 61: 237-255. 
Gottfredson MR and Gottfredson DM (1988) Decision Making in Criminal Justice: Toward the Rational Exercise of Discretion. New York: Plenum Press.

Hodgson J (2002) Hierarchy, bureaucracy, and ideology in French criminal justice: Some empirical observations. Journal of Law and Society 29(2): 227-257.

Holdaway S (1980) The police station. Journal of Contemporary Ethnography 9(1): 79-100.

Ignatieff M (1979) Police and the people: The birth of Mr Peel's 'Blue Locusts'. New Society 49: 443-445.

Johnstone G (2002) Restorative Justice: Ideas, Values, Debates. Portland, OR: Willan.

Latour B (2010) The Making of Law: An Ethnography of the Conseil d'Etat. Cambridge: Polity.

Luhmann N (2013 [1983]) Legitimation durch Verfahren. Frankfurt am Main: Suhrkamp.

Lund C (1998) Law, Power and Politics in Niger: Land Struggles and the Rural Code. Hamburg: LIT.

Martin J (2007) A reasonable balance of law and sentiment: Social order in democratic Taiwan from the policeman's point of view. Law \& Society Review 41(3): 665-698.

Monjardet D (1996) Ce que fait la police: Sociologie de la force publique. Paris: La Découverte.

Nader L (1990) Harmony Ideology: Justice and Control in a Zapotec Mountain Village. Stanford, CA: Stanford University Press.

Oumarou $\mathrm{H}$ (2011) Les modes de régulation de l'appareil judiciaire nigérien. $\mathrm{PhD}$ Thesis, Ecole des Hautes Etudes en Sciences Sociales, Marseille, France.

Owen O (2013) The police and the public: Risk as preoccupation. Sociologus 63(1-2): 59-80.

Povinelli EA (1998) The state of shame: Australian multiculturalism and the crisis of indigenous citizenship. Critical Inquiry 24(2): 575-610.

Reiner R (2000) The Politics of the Police. Oxford: Oxford University Press.

République du Niger (2003) Code Pénal (last modification). Niamey: République du Niger.

Roche D (2006) Dimensions of restorative justice. Journal of Social Issues 62(2): 217-238.

Shiner RA (1994) Aristotle's theory of equity. Loyola of Los Angeles Law Review 27: 1245-1264.

Skolnick JH (1966) Justice without Trial: Law Enforcement in Democratic Society. New York: John Wiley \& Sons.

Steinberg J (2010) Thin Blue: The Unwritten Rules of Policing South Africa. Johannesburg: Jonathan Ball Publishers.

Strathern M (1996) Cutting the network. Journal of the Royal Anthropological Institute 2(3): $517-535$.

Tamari T (2006) Joking pacts in Sudanic West Africa: A political and historical perspective. Zeitschrift für Ethnologie 131(2): 215-243.

Tidjani-Alou M (2006) Corruption in the legal system. In: Blundo G and Olivier de Sardan JP (eds) Everyday Corruption and the State: Citizens and Public Officials in Africa. Cape Town: Philip, 137-176.

Verne M (2004) Das provozierte Geschenk: Rhetoriken des Schnorrens in einem nigrischen Hausadorf: Formen, Folgen und theoretische Implikationen. In: Beck K (ed.) Blick nach vorn: Festgabe für Gerd Spittler zum 65. Geburtstag. Köln: Köppe, 171-185.

Von Benda-Beckmann F and Von Benda-Beckmann K (2006) The dynamics of change and continuity in plural legal orders. Journal of Legal Pluralism 53-54: 1-44.

Waddington PAJ (1999) Policing Citizens: Authority and Rights. London: UCL Press.

Wright M and Galaway B (eds) (1989) Mediation and Criminal Justice: Victims, Offenders and Community. London: SAGE.

\section{Author biography}

Mirco Göpfert is a lecturer in social and cultural anthropology at the University of Konstanz, Germany. He has published numerous articles on security, police work and bureaucracy in Niger and is co-editor of Police in Africa: The Street Level View (Hurst, forthcoming). 